\title{
A study on cow comfort and risk for lameness and mastitis in relation to different types of bedding materials
}

\author{
S. van Gastelen, ${ }^{\star}$ B. Westerlaan, $†$ D. J. Houwers, $\ddagger$ and F. J. C. M. van Eerdenburg ${ }^{\star 1}$ \\ ${ }^{*}$ Department of Farm Animal Health, Faculty of Veterinary Medicine, Utrecht University, 3584 CL Utrecht, the Netherlands \\ †Department Barn Design, Vetvice, $8431 \mathrm{HH}$ Oosterwolde, the Netherlands \\ ‡Division of Clinical Infectiology, Department of Infectious Diseases and Immunology, Faculty of Veterinary Medicine, Utrecht University, \\ 3584 CL Utrecht, the Netherlands
}

\begin{abstract}
The aim was to obtain data regarding the effects of 4 freestall bedding materials (i.e., box compost, sand, horse manure, and foam mattresses) on cow comfort and risks for lameness and mastitis. The comfort of freestalls was measured by analyzing the way cows entered the stalls, the duration and smoothness of the descent movement, and the duration of the lying bout. The cleanliness of the cows was evaluated on 3 different body parts: (1) udder, (2) flank, and (3) lower rear legs, and the bacteriological counts of the bedding materials were determined. The combination of the cleanliness of the cows and the bacteriological count of the bedding material provided an estimate of the risk to which dairy cows are exposed in terms of intramammary infections. The results of the hock assessment revealed that the percentage of cows with healthy hocks was lower (20.5 \pm 6.7 ), the percentage of cows with both damaged and swollen hocks was higher $(26.8 \pm 3.2)$, and the severity of the damaged hock was higher $(2.32 \pm 0.17)$ on farms using foam mattresses compared with deep litter materials [i.e., box compost $(64.0 \pm 10.4,3.5 \pm 4.7,1.85$ \pm 0.23 , respectively), sand $(54.6 \pm 8.2,2.0 \pm 2.8,1.91$ \pm 0.09 , respectively), and horse manure (54.6 \pm 4.5 , $5.5 \pm 5.4,1.85 \pm 0.17$, respectively)]. In addition, cows needed more time to lie down $(140.2 \pm 84.2 \mathrm{~s})$ on farms using foam mattresses compared with the deep litter materials sand and horse manure (sand: $50.1 \pm 31.6 \mathrm{~s}$, horse manure: $32.9 \pm 0.8 \mathrm{~s}$ ). Furthermore, the duration of the lying bout was shorter $(47.9 \pm 7.4 \mathrm{~min})$ on farms using foam mattresses compared to sand $(92.0 \pm 12.9$ $\mathrm{min})$. These results indicate that deep litter materials provide a more comfortable lying surface compared with foam mattresses. The 3 deep litter bedding materials differed in relation to each other in terms of comfort and their estimate of risk to which cows were exposed in terms of intramammary infections [box compost:
\end{abstract}

Received November 18, 2010.

Accepted June 9, 2011.

${ }^{1}$ Corresponding author: F.J.C.M.vanEerdenburg@uu.nl
$17.8 \mathrm{cfu}\left(1.0^{4}\right) \pm 19.4 / \mathrm{g}$; sand: $1.2 \mathrm{cfu}\left(1.0^{4}\right) \pm 1.6 / \mathrm{g}$; horse manure: $110.5 \mathrm{cfu}\left(1.0^{4}\right) \pm 86.3 / \mathrm{g}$ ]. Box compost had a low gram-negative bacterial count compared with horse manure, and was associated with less hock injury compared with foam mattresses, but did not improve lying behavior (lying descent duration: $75.6 \pm 38.8 \mathrm{~s}$, lying bout duration: $46.1 \pm 18.5 \mathrm{~min}$ ). Overall, sand provided the best results, with a comfortable lying surface and a low bacterial count.

Key words: bedding material, lying behavior, hock assessment, bacterial load

\section{INTRODUCTION}

To create an environment for dairy cows in which they feel comfortable is of great importance, both from a welfare and economic perspective. Apart from the dimensions, the comfort of freestalls depends on the type and quality of the bedding material. The bedding material should provide thermal comfort and softness, yet be durable and have sufficient friction to allow rising and lying down without slipping. Finally, bedding material should help in keeping cows clean and healthy while minimizing daily labor requirements (Chaplin et al., 2000).

Sand is a good bedding material (Norring et al., 2008); however, sand has a few drawbacks when used in combination with slatted floors. Composted materials are gaining popularity in European farms because of the possibility of combining them with slatted floors. Box compost is a new bedding material consisting of composted biodegradable waste from households (Groot Antink, 2009). Box compost is heated for $3 \mathrm{~d}$ at $70^{\circ} \mathrm{C}$ to decrease the bacterial count and kill weed seeds. After this heat treatment, a mix of Lactobacillus species is added to the material to compete with possible pathogenic contaminants, thus helping to prevent IMI. Another deep litter material is horse manure, which is made from fresh horse dung and litter. This bedding material provides a soft lying surface, but most likely contains high numbers of fecal bacteria and probably supports the presence of potentially pathogenic bac- 
teria (Carroll and Jasper, 1978). The most important reason for using horse manure in the Netherlands as bedding is that it is free. Foam mattresses are considered one of the best non-deep litter beddings (Fulwider and Palmer, 2004).

Lying behavior is a useful criterion to measure freestall comfort (Haley et al., 2000). Cows prefer, and spend more time lying in, well-bedded, soft and dry stalls (Chaplin et al., 2000; Tucker and Weary, 2004). Cows that spend less time lying in uncomfortable stalls likely spend more time standing in concrete alleyways with the risk of developing claw diseases and injuries (Bell and Weary, 2000; Vokey et al., 2001). Furthermore, an increase in the preparation time required to lie down and a longer duration of this process was observed on a less comfortable lying surface (Müller et al., 1989; Wechsler et al., 2000). This is probably reflecting the cows' hesitation to lie down (Tucker and Weary, 2004). Cows that do not lie down due to an uncomfortable lying surface show behavioral and physiological stress responses, which most likely affect their health and production (Munksgaard et al., 1999).

The degree of hock damage reflects the degree of comfort associated with the lying surface (Rutherford et al., 2008). In several studies, more hock lesions and swellings were found on harder compared with softer surfaces (Weary and Taszkun, 2000; Wechsler et al., 2000; Vokey et al., 2001), and if the lying surface is hard, hock lesions can develop into more severe injuries due to continuous pressure and friction imposed by the lying surface (Schulze Westerath et al., 2007). The effects of lameness are negative for the profitability of a farm (Logue et al., 1993; Cha et al., 2010).

Several cow comfort indices have been developed that are easy to use in a relatively short period of time and are considered a reflection of daily lying behavior (Cook et al., 2005). In addition, an evaluation of cow cleanliness in combination with the determination of the bacteriological count of the bedding material should provide an estimate of the exposure to potential udder pathogens (Hughes, 2001; Ward et al., 2002).

In the present study, box compost, sand, horse manure, and foam mattress were compared with respect to lying behavior, occurrence and severity of hock injuries, cow comfort indices, and hygiene.

\section{MATERIALS AND METHODS}

\section{Study Site and Subjects}

Between February and May 2010, a total of 24 farms with a freestall barn were visited; all were located in the Netherlands. Nine farms used box compost (Sinnige Boxcompost, Damwoude, the Netherlands), 6 farms used sand, 6 farms used foam mattresses (various manufacturers), and 3 farms used horse manure as bedding material (Table 1). All farms were visited once for a time period of $1 \mathrm{~d}$ (approximately from 0900 until $1700 \mathrm{~h}$ ) and the cows studied were all lactating Holstein-Friesian.

\section{Control for Differences}

As well as the type of bedding material, 3 major factors differed between the farms. To compensate for these factors, each farm was given a score for each of the 3 factors: freestall design, bedding characteristics, and rate of overcrowding. The scores were determined on $20 \%$ of the stalls. The first score, reflecting the freestall design, was based upon 5 traits and had a maximum value of 50 (van Eerdenburg et al., 2009):

$1=$ the length of the lying surface, from the rear curb to the middle of the brisket board:

$2=$ the length of the lunge space, from the middle of the brisket board to the front of the stall;

$3=$ stall width $(\mathrm{cm})$; distance between the center of the partitions;

$4=$ height of neck rail $(\mathrm{cm})$; distance between stall bed and neck rail;

$5=$ diagonal distance of neck rail $(\mathrm{cm})$; distance between the rear curb and the neck rail.

A score was given for each trait based upon the dimension of that measurement (Table 2).

The second score reflected the characteristics of the bedding material. This score was based upon 5 measures and had a maximum value of 35 (van Eerdenburg et al., 2009); (1) softness, (2) dryness, (3) cleanliness, (4) surface bedding material, and (5) angle of the lying surface (Table 2). The first 2 variables were measured by performing the knee test [i.e., one drops quickly on one's knees from a standing position and stays on the bedding for $10 \mathrm{~s}$ with all weight on 1 knee (McFarland and Graves, 1995)]. The 3 other measures were determined by observing the stalls and their lying surface and their values added to provide the score for the characteristics of the bedding material.

The last score reflected the overcrowding rate in the barn and had a maximum score of 0 . Each farm was given a score describing the group that was being observed for this study. If the number of freestalls was equal to, or more than, the number of cows present, 0 points were given. When $10 \%$ more cows were present than freestalls available, -5 points were given, and if $>20 \%$ more cows were present than freestalls available, -10 points were given (van Eerdenburg et al., 2009).

In summary, every farm was given 3 scores representing the 3 factors freestall design, bedding charac- 
Table 1. The details of the 24 farms that were visited for this study, sorted by type of bedding material

\begin{tabular}{|c|c|c|c|c|c|c|c|c|c|c|}
\hline $\begin{array}{l}\text { Farm } \\
\text { no. }\end{array}$ & $\begin{array}{l}\text { Bedding } \\
\text { material }\end{array}$ & $\begin{array}{l}\text { No. of } \\
\text { cows }\end{array}$ & $\begin{array}{l}\text { No. of } \\
\text { stalls }\end{array}$ & $\begin{array}{l}\text { No. of } \\
\text { feeding } \\
\text { places }\end{array}$ & $\begin{array}{c}\text { Cleaning } \\
\text { stalls } \\
\text { (frequency/d) }\end{array}$ & $\begin{array}{c}\text { Applying } \\
\text { bedding } \\
\text { material } \\
(\mathrm{n} / \mathrm{wk})\end{array}$ & $\begin{array}{l}\text { Floor } \\
\text { type }\end{array}$ & $\begin{array}{l}\text { Floor- } \\
\text { cleaning } \\
\text { method }\end{array}$ & $\begin{array}{l}\text { Cow } \\
\text { cleaning } \\
\text { brush }\end{array}$ & $\begin{array}{l}\text { Milking } \\
\text { system }\end{array}$ \\
\hline 2 & Box compost & 45 & 65 & 57 & 2 & 3 & Slatted & Robot & Present & Conventional \\
\hline 3 & Box compost & 213 & 195 & 190 & 4 & 1 & Slatted & Robot & Present & Conventional \\
\hline 4 & Box compost & 61 & 65 & 65 & 3 & 2 & Slatted & Robot & Present & Conventional \\
\hline 5 & Box compost & 165 & 170 & 160 & 4 & 2 & Slatted & Robot & Not present & Conventional \\
\hline 8 & Box compost & 155 & 140 & 140 & 4 & 1 & Closed & Scraper & Present & Conventional \\
\hline 9 & Box compost & 154 & 180 & 165 & 2 & 2 & Slatted & Robot & Present & Conventional \\
\hline 10 & Sand & 90 & 89 & 90 & 2 & 5 & Closed & Scraper & Present & Conventional \\
\hline 11 & Sand & 88 & 100 & 100 & 3 & 1 & Closed & Scraper & Present & Conventional \\
\hline 12 & Sand & 156 & 140 & 145 & 3 & 2 & Closed & Scraper & Present & Conventional \\
\hline 13 & Sand & 120 & 200 & 180 & 3 & 3 & Closed & Scraper & Not present & Robotic \\
\hline 19 & Foam mattress & 90 & 120 & 115 & 4 & 2 & Slatted & Scraper & Present & Robotic \\
\hline 20 & Foam mattress & 80 & 81 & 80 & 2 & 1 & Slatted & By hand & Present & Conventional \\
\hline 21 & Foam mattress & 93 & 87 & 90 & 2 & 1 & Slatted & Scraper & Present & Conventional \\
\hline 22 & Horse manure & 120 & 120 & 100 & 3 & 3 & Slatted & Scraper & Present & Conventional \\
\hline 23 & Horse manure & 65 & 83 & 80 & 2 & 4 & Slatted & Scraper & Present & Conventional \\
\hline 24 & Horse manure & 150 & 200 & 190 & 2 & 3 & Closed & Scraper & Not present & Conventional \\
\hline
\end{tabular}

${ }^{1}$ From Sinnige Boxcompost (Damwoude, the Netherlands).

teristics, and rate of overcrowding. These scores were measured to determine whether the differences found in the measured variables (see next sections) between the 4 types of bedding materials were due to the different types of bedding material and not the result of differences in the 3 factors of freestall design, bedding characteristics, and rate of overcrowding.

\section{Two Indices of Cow Comfort}

To determine 2 indices of cow comfort, 5 types of behaviors were evaluated: (1) active in alley (i.e., a cow that was in the alley, engaged in another activity), (2) waiting for the milking parlor/being milked, (3) standing idle in the alley, (4) standing with at least 1 foot in a freestall, and (5) lying in a stall. Four times per day, all cows were counted and placed into 1 of 5 behavioral classes. This was done at 0930, 1130, 1330, and $1530 \mathrm{~h}$ ).

Dividing the cows into 5 different behavioral classes resulted in the measurement of 2 indices of cow comfort: (1) the cow comfort index (CCI; Cook et al., 2005), which is the proportion of cows touching a stall that are actually lying down, and (2) the stall use index (SUI; Overton et al., 2003) which is the proportion of

Table 2. The dimensions of the 5 variables describing freestall design and their corresponding points, and the conditions of the 5 variables describing bedding characteristics and their corresponding points

\begin{tabular}{|c|c|c|c|}
\hline Variable & \multicolumn{3}{|c|}{ Score $^{1}$} \\
\hline \multicolumn{4}{|l|}{ Stall design } \\
\hline Length of the lunge space $(\mathrm{cm})$ & $<60$ & $60-70$ & $>70$ \\
\hline Stall width $(\mathrm{cm})$ & $<110$ & $110-120$ & $>120$ \\
\hline Height neck rail $(\mathrm{cm})$ & $<110$ & $110-120$ & $>120$ \\
\hline Softness & Painful & Not comfortable & Soft \\
\hline Dryness & Wet & Dry & - \\
\hline Cleanliness & Most stalls dirty ( $>40 \%)$ & Some stalls dirty $(1-40 \%)$ & No stalls dirty $(0 \%)$ \\
\hline Surface & Large holes/irregular & Nice and smooth & - \\
\hline Angle of the lying surface & No angle/angle wrong direction & Angle between 3 and $7^{\circ}$ & - \\
\hline
\end{tabular}

${ }^{1}$ The scores 0, 5, and 10 are based upon a welfare scoring system for cow comfort (van Eerdenburg et al., 2009). 
cows present in the pen, not feeding or involved in the milking process, that are lying down in the stall. An average was calculated for both indices; thus, each farm received $1 \mathrm{CCI}$ value and 1 SUI value.

\section{Hock Assessment}

On each farm, the prevalence and severity of skin lesions on the hocks and the prevalence of swollen hocks were recorded. This was done for all cows on each farm and for both hocks of each cow. First, the presence of lesions on and swelling of the hocks were assessed via a simple scoring system (Rutherford et al., 2008) with a 4-point scale: $0=$ no swelling, no lesion; $1=$ lesion, no swelling; $2=$ swelling, no lesion; and $3=$ both lesion and swelling. When a lesion or a swelling was present, its severity was assessed. For the severity of the lesions, a 5-point scoring scale as described by Norring et al. (2008) was used: 1 = some hair loss or broken hairs, $2=$ bare skin visible (hairless patch), $3=$ thickening of skin, $4=$ reddening of skin, and $5=$ open cuts or wounds. To assess the severity of the swelling of the hocks, a 3-point scale was used (modified from Norring et al., 2008): 1 = slight swelling, $2=$ moderate swelling, and $3=$ extreme swelling. Afterward, the proportion of cows with hock assessment score $0,1,2$, and 3 , and the mean severity of the swollen hocks and of the skin lesions on the hocks was calculated.

\section{Cleanliness Score}

The cleanliness of the cows was assessed according to the Dutch Udder Health Centre (UGCN, 2007) scoring system. The cleanliness was scored for all cows in the herd and on 3 different parts of the body: (1) udder, from lateral view, (2) the flank and upper rear legs, and (3) the lower rear legs. For each of these 3 body parts, the cleanliness was scored on a 4-point scale:

$1=$ free of $\operatorname{dirt}(0 \%$ dirt $)$;

$2=$ slightly covered with dirt ( 0 to $10 \%$ dirt);

$3=$ moderately covered with dirt (10 to 30\% dirt);

$4=$ extremely covered with $\operatorname{dirt}(>30 \%$ dirt).

For each farm, a mean cleanliness score was given for each body part and an average overall score was determined representing the rear part of the body, resulting in 4 cleanliness scores per farm. In addition, all cows of each farm were subsequently placed in a cleanliness category based on the average overall cleanliness score representing the rear part of their body. In total, 3 cleanliness categories were distinguished: (1) cleanliness score between 1 and 2, (2) cleanliness score between 2 and 3 , and (3) cleanliness score between 3 and 4 . Thus, for example, if a cow had an overall cleanliness score between 2 and 3, representing the rear part of her body, this cow was placed in cleanliness category 2 . For each farm, the percentage of cows placed in each of these categories was determined.

\section{Lying Behavior}

On each farm, a camera was placed to make video recordings of approximately 15 to 30 freestalls (21.8 \pm 5.8 , mean $\pm \mathrm{SD}$ ). Each recording covered $8 \mathrm{~h}$ (0900 to $1700 \mathrm{~h}$ ) and was analyzed for the following behaviors:

1. Entering stall: whether a cow entered the stall with all 4 feet immediately or whether she started perching (i.e., with 2 front feet in the stall and 2 rear feet in the alley) was recorded upon the time a cow entered the stall. When a cow entered the stall and immediately left again, this cow and her behavior were not included in the analyses, because this behavior might be a dominance behavior and the cow did not intend to lie down in the stall.

2. Perching: if a cow started perching, the duration was recorded and what made the perching behavior end; the cow could either leave the stall or still enter the stall with all 4 feet.

3. Lying down movement: the descent movement of the cows was divided into 2 phases: (1) the preparation phase, and (2) the actual lying descent movement. During the first phase, the cow entered the stall with all 4 feet and moved her head in pendulum movements close to the ground while standing, then the cow bent 1 of her carpi while standing, and then the lying descent began with the placement of 1 rear foot slightly in front of the other and then kneeling on 1 carpus. During the second phase of the lying descent movement, the cow knelt on both carpi and, thereafter, 1 hind leg was placed underneath the abdomen as, at the same time, the hind quarters were lowered. Finally, the cow settled from the carpals and rested by distributing her weight on her lower hind leg, thigh, and abdomen supported by the front legs (Schnitzer, 1971; Lydfors, 1989). The exact starting and ending time of both phases of the lying descent movement was recorded and the average duration (in seconds) of lying descent phases 1 and 2 was determined.

4. Lying descent problems and smoothness: the number of problems during the lying descent procedure was recorded. This included intentions, which were defined as the lying descent 
procedures by which the sweeping movements of the head were not being followed by further lying descent movements. Also, interruptions were recorded, defined as the lying descent procedures by which the bending of the foreleg in the air and the kneeling on 1 foreleg was not followed by further lying descent movements (Lidfors, 1989). Furthermore, the smoothness of the lying descent movement was determined. Every lying descent movement was given a smoothness score according to a 5 -point scale as described by Chaplin and Munksgaard (2001).

5. Lying bout duration: once a cow was lying (i.e., as soon as phase 2 of the lying descent movement finished), the recording of the duration of that lying bout began.

6. Rising movement: similar to the lying descent movements, the ascent movements were divided into 2 different phases. During the first phase, the cow raised her brisket from the ground and lunged forward with head and neck to pull her rear feet underneath, while the flank was still in contact with the ground. During the second phase, the cow placed her weight on both carpi while her rear legs straightened until a balanced, standing position, in which all 4 feet were in contact with the ground, was achieved (Schnitzer, 1971; Lidfors, 1989). Again, the exact starting and ending time of both phases of the ascent movement was recorded and the average duration (in seconds) of arising phases 1 and 2 was determined.

7. Rising problems and smoothness: the number of problems during the ascent procedure was measured; for instance, when the lunging forward did not result in the placement of the rear feet underneath the cow. Furthermore, the smoothness of the ascent movement was determined. Every ascent movement was given a smoothness score according to a 5 -point scale (Chaplin and Munksgaard, 2001).

8. Another lying bout: whether a cow left the stall or started a new lying bout was recorded after the cow had been standing. When a cow started a new lying bout, the above mentioned points 3 to 7 were recorded again.

\section{Bacteriological Sampling and Analyses}

On each farm, a bedding sample was collected from $20 \%$ of the stalls according to the method of systematic sampling. The sample was collected from the place where the udder was positioned when cows were lying down. This was approximately in the middle of the width and $40 \mathrm{~cm}$ from the curb of the stall (Hogan et al., 1989). An equal sample size of bedding materials was collected from each stall by using a tablespoon (the tablespoon had a volume of $15 \mathrm{~mL}$ and the sample was leveled each time the tablespoon was filled). The spoon was cleaned beforehand with soap and water of $>65^{\circ} \mathrm{C}$, air-dried and transported in a plastic bag to keep it clean. The same spoon was used to collect the samples from each stall (the samples were going to be mixed afterward). From the farms, using foam mattresses as bedding material, a sample was taken from its additional top layer (this top layer was necessary when foam mattresses were used as bedding material to absorb moisture). All farms with foam mattresses as bedding material used sawdust as an additional top layer, which was approximately $5 \mathrm{~mm}$ thick. All bedding material samples from the different stalls were placed together in 1 container of $500 \mathrm{~mL}$ and mixed/blended to create a homogeneous sample. From this homogeneous sample, a smaller sample $(10 \mathrm{~mL})$ was taken and placed into a storage tube with screw cap and stored at $-18^{\circ} \mathrm{C}$ until analysis. The samples were frozen immediately after the farm was visited. All farms were visited within a period of $3 \mathrm{mo}$, resulting in some samples being frozen 3 mo before analysis, whereas other samples were frozen 1 wk before analysis.

The bacteriological analyses were performed at the Veterinary Microbiological Diagnostic Centre of Utrecht University. A few hours before analyses, the samples were taken out of the freezer and placed at $3.5^{\circ} \mathrm{C}$ to thaw the bedding material slowly. A series of dilutions of 1 part to 10 of $0.9 \% \mathrm{NaCl}$ was made of each of the bedding material samples. These serial dilutions were plated onto 2 different kinds of growth media; sheep blood agar and MacConkey agar No. 3 (Hogan et al., 1999). The sheep blood agar is a growth medium on which both gram-negative and gram-positive bacteria grow. MacConkey agar No. 3 agar is a medium containing bile salts which inhibit growth of gram-positive bacteria. Three dilutions were plated on both media: 1 in 100, 1 in 1,000, and 1 in 10,000 on the sheep blood agar and 1 in 10, 1 in 100, and 1 in 1,000 on the MacConkey agar No. 3. Plates were incubated for $18 \mathrm{~h}$ at $37^{\circ} \mathrm{C}$ and the number of colony-forming units was counted (Hogan and Smith, 1997).

In addition, for each farm, the most recent ( $<3 \mathrm{wk}$ ) bulk milk bacteriological count, determined by the standard plate count method (Rysanek et al., 2009), was obtained from the dairy processing plant.

\section{Data Analyses}

The data were statistically analyzed using SPSS Statistics 17.0 (IBM SPSS, New York, NY). In total, 30 
variables were measured, belonging to 1 of the 5 assessments: (1) cow comfort indices, (2) hock assessment, (3) cleanliness score, (4) lying behavior, and (5) bacteriological sampling. Each variable had a total of 24 values, each representing a farm. These 24 values were divided into 4 groups, each representing a different type of bedding material: box compost $(\mathrm{n}=9)$, sand $(\mathrm{n}=$ $6)$, foam mattresses $(n=6)$, and horse manure $(n=3)$. Two analyses were performed for each group: first, the descriptive analyses to determine the mean, the standard deviation, and the standard error of the means; then, the Kolmogorov-Smirnov test was performed to determine whether the data for each group fitted a normal distribution. For all 30 variables, the data of the 4 bedding materials were normally distributed. A 1-way ANOVA was conducted to determine whether the means of the 4 groups (box compost, sand, foam mattresses, and horse manure) differed from each other for each variable. If a difference was found with the 1-way ANOVA, the Bonferroni post-hoc test was conducted to determine which bedding materials differed.

To determine whether the differences found in the 2 indices of cow comfort between the 4 types of bedding materials, were due to the different types of bedding material and not the result of differences in the milking procedure (conventional and robotic), the influence of the 2 different milking procedures was analyzed.

In addition, each farm was given 3 scores representing the factors of stall design, bedding characteristics, and rate of overcrowding. This resulted in 24 values per factor. The 30 variables measured consisted of 24 values and for this analysis, these 24 values were not divided into groups. Again, the descriptive analyses were performed to determine the mean, the standard deviation, and the standard error of the means. Then, the Kolmogorov-Smirnov test was performed to determine whether the data of the 30 variables and the 3 factors fitted a normal distribution. For all, the data were normally distributed. Then, the Pearson correlation test was applied for all 30 variables to determine whether they correlated with the 3 factors stall design, bedding characteristics, and rate of overcrowding.

Before analyzing the effect of the different types of bedding material on the cleanliness scores, the influence of some management factors was assessed: (1) the type of the floor (closed floor vs. slatted floor), (2) the cleaning method of the floor (robot vs. scraper system vs. by hand), and (3) the presence of a brush on which cows could clean themselves (present vs. not present). Whether these 3 management factors correlated with the 4 mean cleanliness scores for each farm (udder, flank and upper rear legs, lower rear legs, and the overall average representing the rear part of the body) and the percentage of cows within the 3 cleanliness categories was determined.

As mentioned earlier, the farms did not only differ in the type of bedding material used, but also in 4 management factors: (1) milking procedure, (2) type of floor, (3) type of floor cleaning, and (4) presence of a brush. To analyze the influence of these 4 management factors, the data by variable were no longer divided into the 4 groups representing the different types of bedding materials, but divided into the number of groups representing a different management factor. For the milking procedure, the data of each variable were divided into 2 groups: (1) conventional milking (n $=19)$, and $(2)$ robotic milking $(\mathrm{n}=5)$. For the type of floor, the data of each variable were divided into 2 groups: (1) slatted floor $(\mathrm{n}=16)$, and (2) closed floor $(\mathrm{n}=8)$. For the floor cleaning system, the data of each variable were divided into 3 groups: (1) scraper $(\mathrm{n}=14),(2)$ robot $(\mathrm{n}=8)$, and $(3)$ by hand $(\mathrm{n}=2)$. For the presence of a cleaning brush for the cows, the data of each variable were divided into 2 groups: (1) brush present $(\mathrm{n}=18)$, and (2) brush not present (n $=6$ ). Then, each group by each management factor was statistically analyzed. First, a descriptive analysis was done to determine the mean, the standard deviation, and the standard error of the means. Then, the Kolmogorov-Smirnov test was performed to determine whether the data for each group fit a normal distribution. For all 4 management factors, the different groups within the 30 variables fit a normal distribution and, parametric tests were conducted. For the management factors of milking procedure, floor type, and presence of a brush, the independent-samples $t$-test was performed to determine whether the means of the 2 groups differed from each other for each variable. For the management factor of floor cleaning system, the 1-way ANOVA was conducted to determine whether the means of the 3 groups differed from each other by each variable. If a difference was found with the 1-way ANOVA, the Bonferroni post-hoc test was conducted to determine between which floor cleaning system the means of the measured variable differed. Overall, a $P$-value $<0.05$ was considered statistically significant, and a $P$-value between 0.05 and 0.10 was considered a trend.

\section{RESULTS}

\section{Two Indices of Cow Comfort}

No differences were found in both indices of cow comfort (CCI and SUI) between the different types of bedding material (CCI: $P=0.239$, SUI: $P=0.433$; respectively, box compost: $81.2 \pm 8.1,68.1 \pm 10.6$; sand: 
$86.0 \pm 8.7,72.2 \pm 13.5$; horse manure: $87.4 \pm 6.3,78.9$ \pm 6.6 ; foam mattresses: $78.1 \pm 7.0,67.8 \pm 8.3$ ). In addition, no difference was found in both indices of cow comfort between the 2 types of milking systems (CCI: $P=0.710$, robotic: $80.0 \pm 6.8$, conventional: $83.0 \pm$ 8.4; SUI; $P=0.494$, robotic: $68.4 \pm 7.9$, conventional: $71.0 \pm 11.3)$.

\section{Hock Assessment}

The percentage of cows with healthy hocks (no injury or swelling; Figure 1A) was lower on farms with foam mattresses $(20.5 \pm 6.7)$ compared with farms using deep litter materials [box compost $(64.0 \pm 10.5 ; P<$ $0.001)$, sand $(54.6 \pm 8.2 ; P<0.001)$, and horse manure $(54.6 \pm 4.5 ; P<0.001)]$. The percentage of cows having damaged hocks (Figure 1B) was lower on farms using box compost $(25.8 \pm 3.8)$ compared with farms using sand $(41.4 \pm 6.5 ; P=0.006)$ and foam mattresses (42.1 $\pm 9.6 ; P=0.002)$. Furthermore, the percentage of cows having swollen hocks (Figure 1C) was lower on farms using sand $(2.1 \pm 1.7)$ compared with farms using foam mattresses $(10.6 \pm 3.4 ; P=0.005)$. The percentage of cows having injured and swollen hocks (Figure 1D) was higher on farms with foam mattresses $(26.8 \pm 3.2)$ compared with farms using deep litter bedding materials in their freestalls [box compost $(3.5 \pm 4.7 ; P<0.001)$, sand $(2.0 \pm 2.8 ; P<0.001)$, and horse manure $(5.5 \pm$ $5.4 ; P<0.001)]$.

In addition, the severity score of the injured hocks (Figure 2A) was higher on farms with foam mattresses $(2.32 \pm 0.17)$ compared with box compost $(1.85 \pm 0.23$; $P<0.001)$, sand $(1.91 \pm 0.09 ; P=0.006)$, and horse manure $(1.85 \pm 0.17 ; P=0.011)$, and the severity score of the swollen hocks (Figure 2B) tended to be higher on farms using horse manure $(1.46 \pm 0.84)$ compared with sand $(1.13 \pm 0.48 ; P=0.091)$.

Furthermore, a correlation was found between score of the bedding characteristics and the data of the hock assessment. With an increasing score for the bedding characteristics (softer and dryer), the severity of the injured hocks was lower $(\mathrm{r}=-0.405, P=0.05)$.

\section{Cleanliness Score}

No differences were found between the different types of bedding materials in all the cleanliness variables measured [cleanliness score of the udder (box compost: 1.83 \pm 0.21 , sand: $1.76 \pm 0.24$, horse manure: $1.76 \pm 0.07$, foam mattresses: $2.00 \pm 0.19$ ), flank (box compost: 2.33 \pm 0.33 , sand: $2.26 \pm 0.28$, horse manure: $2.15 \pm 0.13$, foam mattresses: $2.59 \pm 0.19$ ), legs (box compost: 2.93 \pm 0.41 , sand: $3.01 \pm 0.18$, horse manure: $2.82 \pm 0.07$, foam mattresses: $3.28 \pm 0.27$ ), and rear part body (box compost: $2.36 \pm 0.29$, sand: $2.34 \pm 0.19$, horse manure: $2.24 \pm 0.09$, foam mattresses: $2.62 \pm 0.21)]$ and the different cleanliness classes [class 1 (box compost: 17.85 \pm 11.06 , sand: $19.43 \pm 6.19$, horse manure: $21.81 \pm$ 2.77, foam mattresses: $7.61 \pm 6.30$ ), class 2 (box compost: $60.78 \pm 12.04$, sand: $61.42 \pm 6.72$, horse manure: $65.13 \pm 2.40$, foam mattresses: $58.67 \pm 6.41$ ), and class 3 (box compost: $21.37 \pm 18.33$, sand: $19.15 \pm 10.99$, horse manure: $13.06 \pm 4.28$, foam mattresses: $33.72 \pm$ 11.81)]

No correlations were found between the cleanliness scores and the scores for freestall design, bedding characteristics, and overcrowding. In addition, no correlations were found between the cleanliness scores of any body part and the 3 management factors: floor type, type of floor cleaning system, and the presence of a brush.

\section{Lying Behavior}

The duration of lying descent phase 1 was longer with foam mattresses (140.2 $\pm 84.2 \mathrm{~s})$ compared with sand $(50.1 \pm 31.6 \mathrm{~s} ; P=0.038)$ and horse manure $(32.9$ $\pm 0.8 \mathrm{~s} ; P=0.046$; Figure $3 \mathrm{~A})$.

The lying bout tended to be longer when horse manure $(105.8 \pm 14.2 \mathrm{~min})$ was used as bedding material compared with foam mattresses $(71.7 \pm 10.2 \mathrm{~min} ; P=$ 0.067; Figure 3B). Furthermore, both lying bout durations were measured when cows performed successive lying bouts (i.e., a cow stood up and then immediately lay down again in the same freestall; Figure 3C). The duration of the first successive lying bout was longer on farms using sand (92.0 \pm 12.9 min) compared with farms using either foam mattresses $(47.9 \pm 7.4 \mathrm{~min}$; $P<0.001)$ or box compost $(46.1 \pm 18.5 \mathrm{~min} ; P<$ 0.001; Figure 3C). In addition, the duration of the first successive lying bout was longer on farms using horse manure $(76.5 \pm 4.3 \mathrm{~min})$ compared with farms using box compost $(P=0.024)$.

No differences were found between the different types of bedding material in all other lying behavior variables measured [perching duration (box compost: $9.0 \pm 2.6$ min, sand: $6.7 \pm 1.5 \mathrm{~min}$, horse manure: $5.1 \pm 0.5 \mathrm{~min}$, foam mattresses: $6.5 \pm 2.9 \mathrm{~min}$ ), duration of lying descent phase 2 (box compost: $5.1 \pm 0.4 \mathrm{~s}$, sand: $5.2 \pm$ $0.4 \mathrm{~s}$, horse manure: $4.6 \pm 0.5 \mathrm{~s}$, foam mattresses: 5.6 $\pm 0.3 \mathrm{~s}$ ), duration of ascent phase 1 (box compost: 4.5 $\pm 0.8 \mathrm{~s}$, sand: $4.8 \pm 1.0 \mathrm{~s}$, horse manure: $4.3 \pm 0.7 \mathrm{~s}$, foam mattresses: $4.8 \pm 0.9 \mathrm{~s}$ ), duration of ascent phase 2 (box compost: $4.6 \pm 1.2 \mathrm{~s}$, sand: $4.3 \pm 0.7 \mathrm{~s}$, horse manure: $4.0 \pm 0.5 \mathrm{~s}$, foam mattresses: $3.9 \pm 0.6 \mathrm{~s}$ ), entering stall with all 4 feet (box compost: $18.5 \pm 9.7 \%$, sand: $22.9 \pm 16.5 \%$, horse manure: $20.0 \pm 10.5 \%$, foam mattresses: $31.0 \pm 15.5 \$$ ), entering stall with perch- 

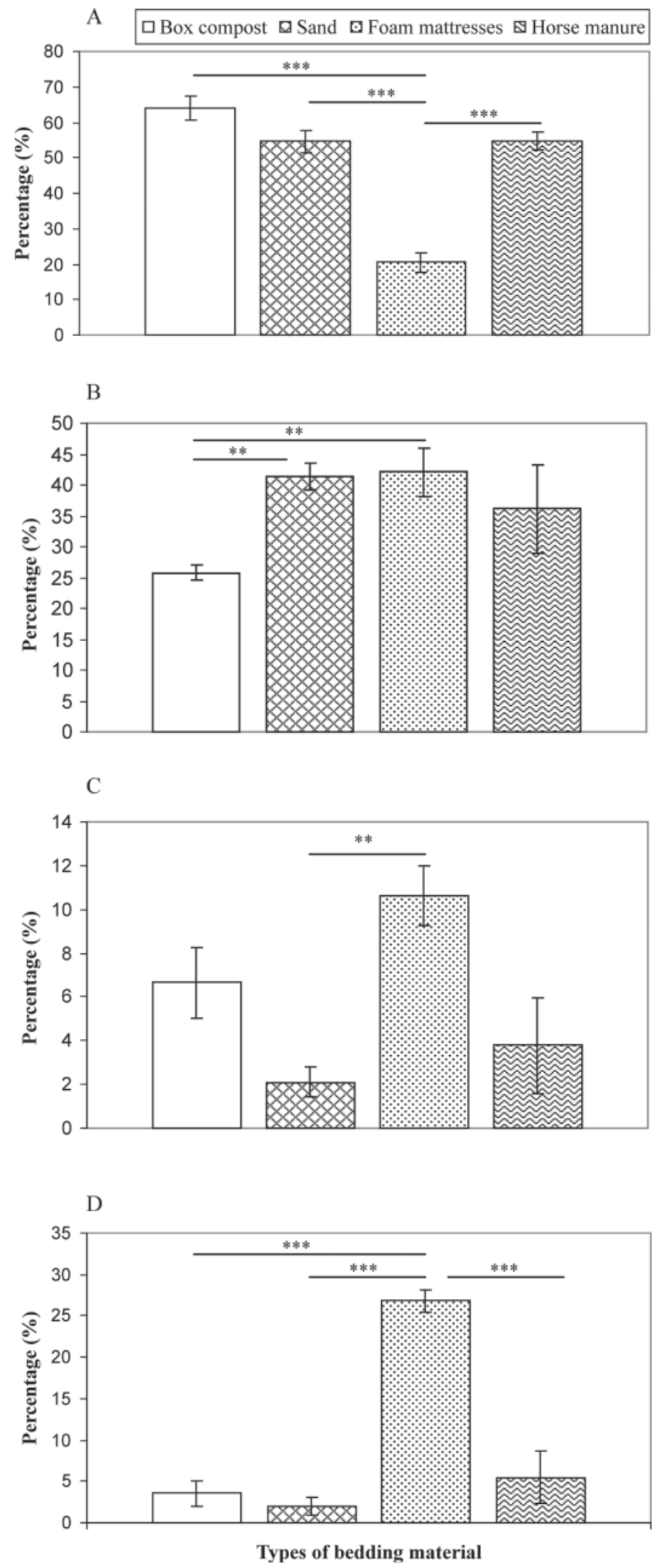

Figure 1. The percentage of cows having (A) healthy hocks, (B) injured hocks, (C) swollen hocks, and (D) injured and swollen hocks for the 4 types of bedding material: box compost (Sinnige Boxcompost, Damwoude, the Netherlands; $\mathrm{n}=9$ ), sand $(\mathrm{n}=6)$, foam mattresses ( $\mathrm{n}$ $=6)$, and horse manure $(\mathrm{n}=3)$. The error bars represent the standard error of the means $\left({ }^{* *} P<0.01 ;{ }^{* * *} P<0.001\right)$. ing behavior (box compost: $81.5 \pm 9.7 \%$, sand: $77.1 \pm$ $16.5 \%$, horse manure: $80.0 \pm 10.5 \%$, foam mattresses: $69.0 \pm 15.5 \%$ ), entering stall with 4 feet after perching (box compost: $55.1 \pm 10.9 \%$, sand: $59.4 \pm 20.0 \%$, horse manure: $54.5 \pm 8.7 \%$, foam mattresses: $60.2 \pm 13.4 \%$ ), and leaving stall after perching (box compost: $44.9 \pm$ $10.9 \%$, sand: $40.6 \pm 20.0 \%$, horse manure: $45.5 \pm 8.7 \%$, foam mattresses: $39.8 \pm 13.4 \%)$ ].

In addition, a correlation was found between the duration of the first lying bout and rate of overcrowding. With a decreasing overcrowding score (from score 0 to -10 ; more overcrowding), the duration of the first lying bout decreased $(\mathrm{r}=0.559, P<0.001)$. No further correlations were found between the data of the lying behavior and the scores for stall design, bedding characteristics, and overcrowding.

\section{Bacteriological Analyses}

The only difference in the number colony-forming units per gram of bedding material on sheep blood agar was found between sand $\left[25.9 \pm 14.8 \mathrm{cfu}\left(\times 1.0^{6}\right) / \mathrm{g}\right]$ and box compost $\left[94.0 \pm 32.9 \mathrm{cfu}\left(\times 1.0^{6}\right) / \mathrm{g} ; P=\right.$ 0.007]; the number of colony-forming units of both gram-positive and gram-negative bacteria was lower in $1 \mathrm{~g}$ of sand compared with $1 \mathrm{~g}$ of box compost (Figure $4 \mathrm{~A})$. Figure $4 \mathrm{~B}$ presents the number of colony-forming units per gram of bedding material on MacConkey agar No. 3. Differences were found between box compost $\left[17.8 \pm 19.4 \mathrm{cfu}\left(\times 1.0^{4}\right) / \mathrm{g}\right]$ and horse manure $(110.5$ $\left.\pm 86.3 \mathrm{cfu}\left(\times 1.0^{4}\right) / \mathrm{g} ; P=0.001\right]$, between sand $[1.2 \pm$ $\left.1.6 \mathrm{cfu}\left(\times 1.0^{4}\right) / \mathrm{g}\right]$ and horse manure $(P<0.001)$, and between the top layer of foam mattresses $[15.7 \pm 11.0$ cfu $\left.\left(\times 1.0^{4}\right) / \mathrm{g}\right]$ and horse manure $(P=0.002)$.

No correlation was found between the number of colony-forming units per gram of bedding material on the MacConkey agar No. 3 and the number of colonyforming units found in the bulk milk $(\mathrm{r}=0.235, P=$ 0.40 ). A trend was found between the number of colonyforming units per gram of bedding material found on the sheep blood agar and the number of colony-forming units found in the milk from the tank $(\mathrm{r}=0.429, P=$ 0.10 ; Figure 5).

\section{DISCUSSION}

The cow comfort indices CCI and SUI did not differ between the 4 types of bedding material and between the 2 types of milking systems. The diurnal variation of both indices of cow comfort is considerable and should be taken into account. Thus, the measurement of these 2 indices of cow comfort on a certain time point does not reflect the magnitude of the average index of comfort obtained throughout the rest of the day, nor are 


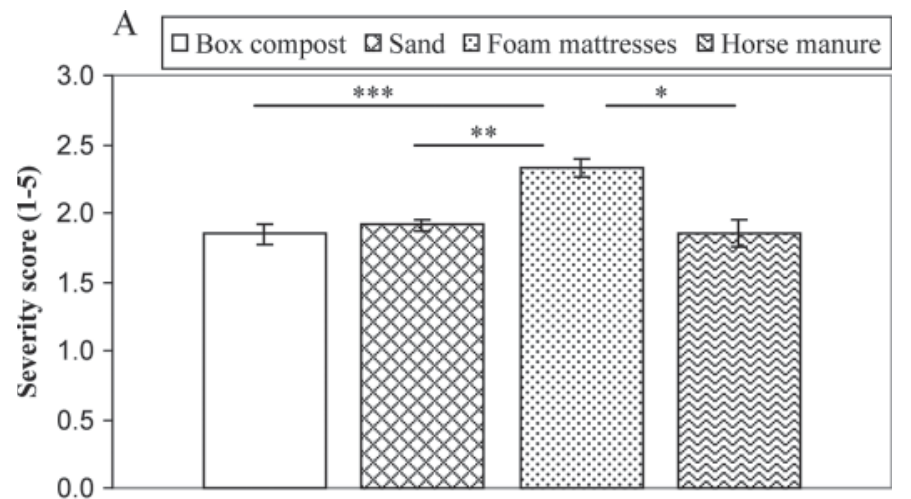

B

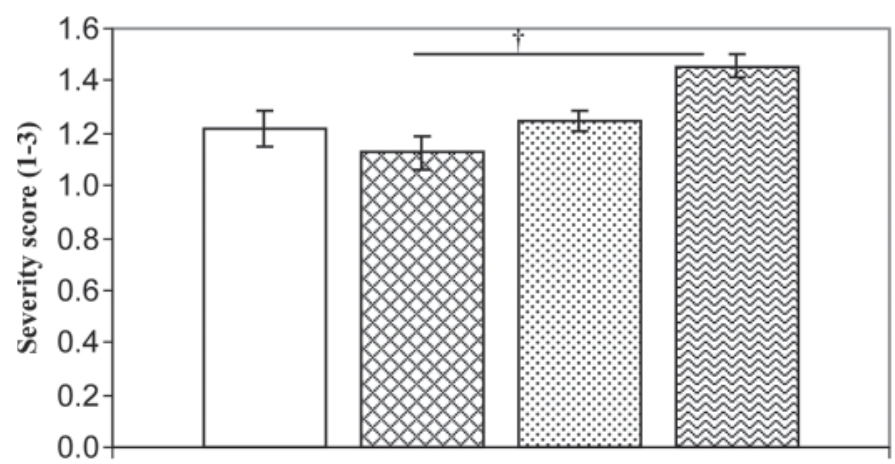

Types of bedding material

Figure 2. (A) The severity of the injured hocks based on a 5-point scale, and (B) the severity of swollen hocks based on a 3-point scale for 4 different types of bedding material: box compost (Sinnige Boxcompost, Damwoude, the Netherlands; $\mathrm{n}=9)$, sand $(\mathrm{n}=6)$, foam mattresses $(\mathrm{n}=6)$, and horse manure $(\mathrm{n}=3)$. The error bars represent the standard error of the means $\left(\dagger P<0.10\right.$; ${ }^{*} P<0.05$; ${ }^{* *} P<$ $0.01 ; * * * P<0.001)$.

the indexes on a certain time point associated with the time budgets of individual cows within the pen (Cook et al., 2005).

Interesting findings from the bacteriological analyses were the results from box compost. The bacterial load of gram-positive bacteria per $1 \mathrm{~g}$ of box compost was relatively large compared with that of gram-negative bacteria. The high gram-positive bacteria load in box compost is because box compost is inoculated with gram-positive bacteria (Lactobacillus species) after the heating process to help decrease the growth of potentially infectious gram-negative environmental bacteria. The phenomenon called colonization resistance (van der Waaij et al., 1971) may apply in this case. That the bacterial load of gram-negative bacteria in box compost did not differ from that in sand (a poor environment for bacterial growth) is an interesting finding.

A higher overcrowding rate was associated with a shorter duration of the first lying bout. This result supports Fregonesi et al. (2007), who found that the lying
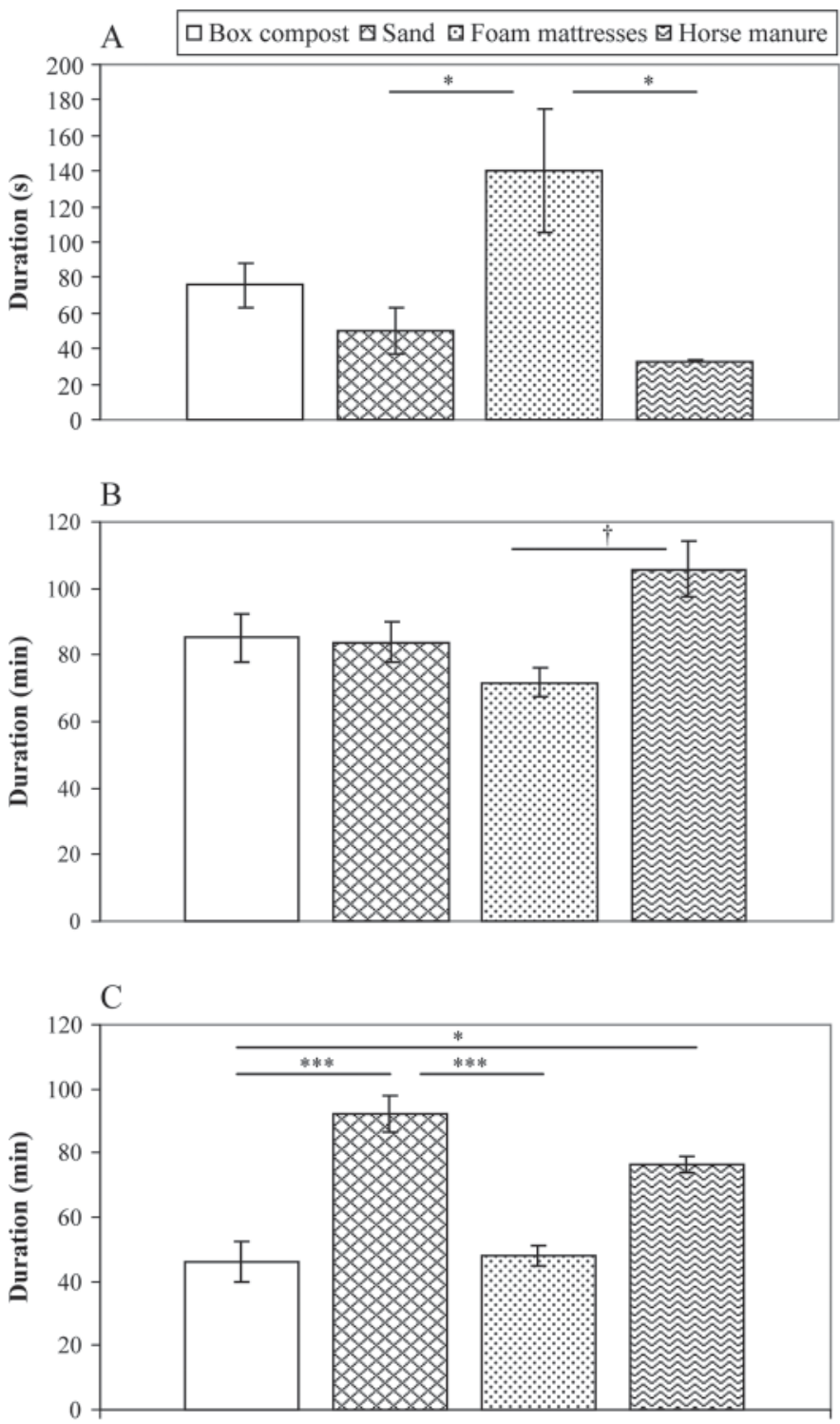

Types of bedding material

Figure 3. (A) The duration of lying descent phase 1, (B) the duration of the first lying bout, and $(\mathrm{C})$ the duration of the successive lying bout for 4 different types of bedding material: box compost (Sinnige Boxcompost, Damwoude, the Netherlands; $\mathrm{n}=9)$, sand $(\mathrm{n}=6)$, foam mattresses $(\mathrm{n}=6)$, and horse manure $(\mathrm{n}=3)$. The error bars represent the standard error of the means $\left(\dagger P<0.10{ }^{*} P<0.05\right.$; ${ }^{* * *} P<$ $0.001)$.

time of dairy cows was decreased when the stocking rate increased.

The duration of the first successive lying bout was longer on farms using sand or horse manure compared with farms using either foam mattresses or box compost. This is probably explained by the difference between the beddings in softness and compressibility. The longer lying bout duration with horse manure and sand confirms the results found in a series of studies in which 

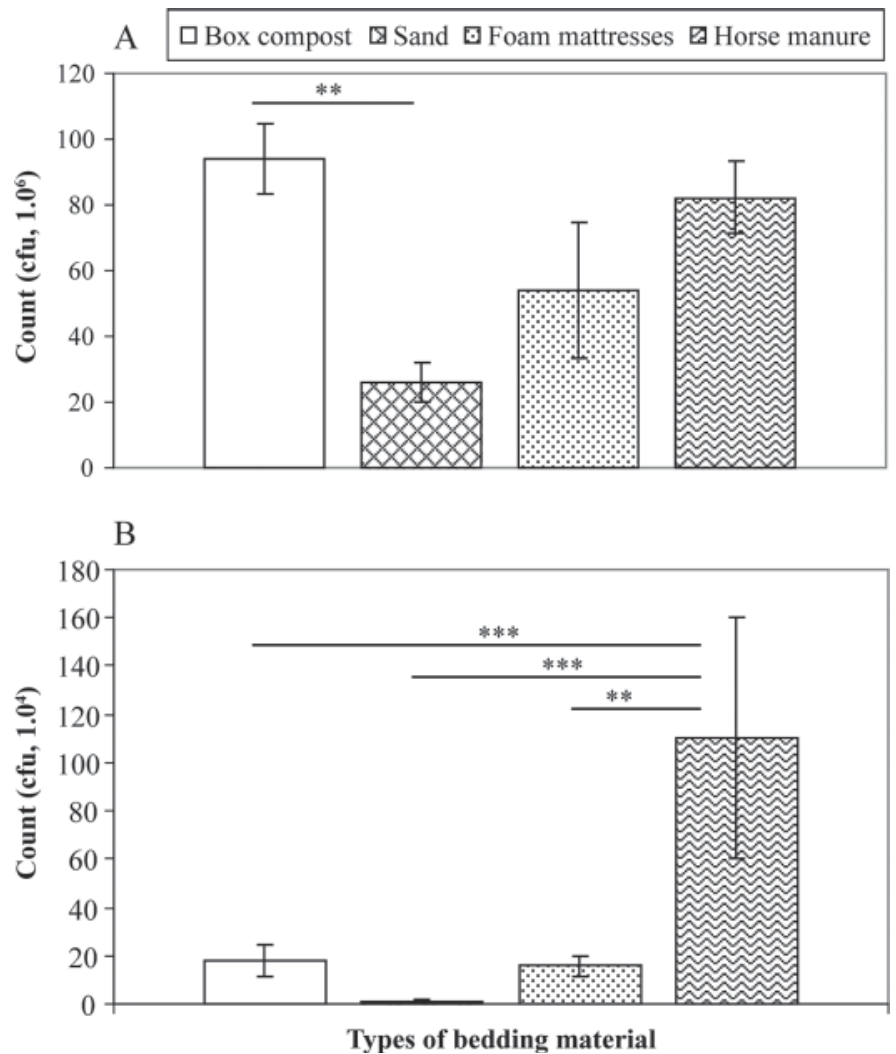

Figure 4. (A) The number of colony-forming units per gram of bedding material found on the sheep blood agar and (B) the number of colony-forming units per gram of bedding material found on the MacConkey agar No. 3. Box compost (Sinnige Boxcompost, Damwoude, the Netherlands; $\mathrm{n}=9)$, sand $(\mathrm{n}=6)$, foam mattresses ( $\mathrm{n}$ $=6)$, and horse manure $(\mathrm{n}=3)$. The error bars represent the standard error of the means $\left({ }^{* *} P<0.01,{ }^{* * *} P<0.001\right)$.

greater softness of the bedding material associated with increased lying times (Chaplin et al., 2000). Their finding that softer lying surfaces resulted in longer total lying times by cows lying down more frequently, but for shorter periods of time, was not supported in the present study.

Cows housed on a less comfortable lying surface need more time to prepare for lying descent and show longer lying descent movements (Wechsler et al., 2000). This may reflect the cows' hesitation to lie down (Tucker and Weary, 2004). Supporting observations were made in the present study; lying descent phase 1 was longer with foam mattresses compared with sand and horse manure. The foam mattresses provided a less comfortable lying surface than the deep litter materials.

If the score for the characteristics of the bedding material increased (a better score for dryness and softness) the severity of the injuries decreased. This is probably due to wet bedding material resulting in the skin of the hocks becoming fragile, increasing the risk for bacterial infections.

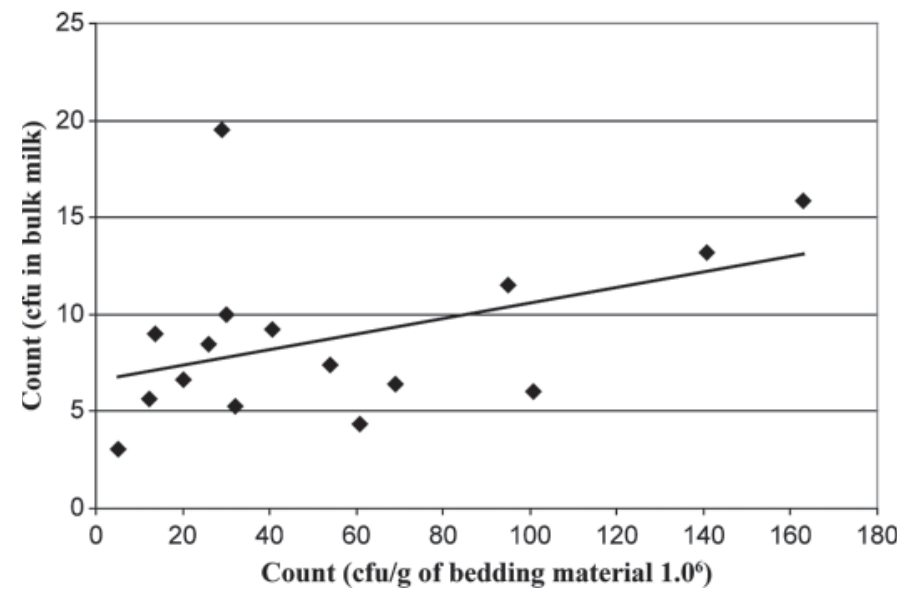

Figure 5. The correlation between the number of colony-forming units per gram of bedding material found on the sheep blood agar and the number of colony-forming units in the bulk milk (determined with the standard plate count method; Rysanek et al., 2009); $\mathrm{n}=16, \mathrm{r}=$ $0.429, P=0.10$

\section{CONCLUSIONS}

From the deep litter materials compared, sand had a low percentage of swollen hocks, a low percentage of injured and swollen hocks, greatest successive lying bouts, and a low bacterial count, giving the best overall results. Foam mattresses resulted in the lowest percentage of healthy hocks, highest duration of lying descent in phase 1 and a low duration of successive lying bouts.

No clear preference can be given to either horse manure or box compost. Horse manure was associated with cows lying down for a long time without hesitation to lie down, but has a high risk of more severe hock injury because of the high number of gram-positive and gramnegative counts. Box compost had a low gram-negative bacteria count and was associated with healthy hocks, but does not seem to improve the cows' lying behavior.

\section{ACKNOWLEDGMENTS}

All cooperating dairy farmers are gratefully thanked for their generous hospitality. Furthermore, Guido Sinnige (Sinnige Boxcompost, Damwoude, the Netherlands) and Bert van Niejenhuis (Department Cow Signals Training Company, Vetvice, Bergharen, the Netherlands) are acknowledged for their help.

\section{REFERENCES}

Bell, E., and D. M. Weary. 2000. The effects of farm environment and management on laminitis. Pages 179-189 in Proc. 35th Annual Pacific Northwest Animal Nutrition Conference, Spokane, WA.

Carroll, E. J., and D. E. Jasper. 1978. Distribution of Enterobacteriaceae in recycled manure bedding on California dairies. J. Dairy Sci. $61: 1498-1508$. 
Cha, E., J. A. Hertl, D. Bar, and Y. T. Gröhn. 2010. The cost of different types of lameness in dairy cows calculated by dynamic programming. Prev. Vet. Med. 97:1-8.

Chaplin, S. J., and L. Munksgaard. 2001. Evaluation of a simple method for assessment of rising behavior in tethered dairy cows. Anim. Sci. 72:191-197.

Chaplin, S. J., G. Tierney, C. Stockwell, D. N. Logue, and M. Kelly. 2000. An evaluation of mattresses and mats in two dairy units. Appl. Anim. Behav. Sci. 66:263-272.

Cook, N. B., T. B. Bennett, and K. V. Nordlund. 2005. Monitoring indices of cow comfort in free-stall-housed dairy herds. J. Dairy Sci. $88: 3876-3885$

Fregonesi, J. A., C. B. Tucker, and D. M. Weary. 2007. Overstocking reduces lying time in dairy cows. J. Dairy Sci. 90:3349-3354.

Fulwider, W. K., and R. W. Palmer. 2004. Use of impact testing to predict softness, cow preference, and hardening over time of stall bases. J. Dairy Sci. 87:3080-3088.

Groot Antink, M. 2009. Boxcompost voor koe in opmars. Veldpost 24:17.

Haley, D. B., J. Rushen, and A. M. Passillé. 2000. Behavioral indicators of cow comfort: Activity and resting behavior of dairy cows in two types of housing. Can. J. Anim. Sci. 80:257-263.

Hogan, J. S., V. L. Bogacz, L. M. Thompson, S. Romig, P. S. Schoenberger, W. P. Weiss, and K. L. Smith. 1999. Bacterial counts associated with sawdust and recycled manure bedding treated with commercial conditioners. J. Dairy Sci. 82:1690-1695.

Hogan, J. S., and K. L. Smith. 1997. Bacteria counts in sawdust bedding. J. Dairy Sci. 80:1600-1605.

Hogan, J. S., K. L. Smith, K. H. Hoblet, D. A. Todhunter, P. S. Schoenberger, W. D. Hueston, D. E. Pritchard, G. L. Bowman, L. E. Heider, B. L. Brockett, and H. R. Conrad. 1989. Bacterial counts in bedding materials used on nine commercial dairies. J. Dairy Sci. $72: 250-258$.

Hughes, J. 2001. A system for assessing cow cleanliness. In Pract. 23:517-524.

Lidfors, L. 1989. The use of getting up and lying down movements in the evaluation of cattle environments. Vet. Res. Commun. 13:307-324.

Logue, D. N., J. E. Offer, and S. A. Kempson. 1993. Lameness in dairy cattle. Ir. Vet. J. 46:47-58

McFarland, D. F., and R. E. Graves. 1995. A case study with dairy cattle: Free stalls. Pages 277-293 in Animal behavior and the Design of Livestock and Poultry systems. Vol. 84. Northeast Regional Agricultural Engineering Service, Indianapolis, IN.

Müller, C., J. Ladewig, H. H. Thielscher, and D. Smidt. 1989. Behavior and heart rate of heifers housed in tether stanchions without straw. Physiol. Behav. 46:751-754.

Munksgaard, L., K. L. Ingvartsen, L. J. Pedersen, and V. K. Nielsen. 1999. Deprivation of lying down affects behavior and pituitaryadrenal axis responses in young bulls. Acta Agric. Scand. A Anim. Sci. 49:172-178.

Norring, M., E. Manninen, A. M. de Passillé, J. Rushen, L. Munksgaard, and H. Saloniemi. 2008. Effect of sand and straw bedding on the lying behavior, cleanliness, and hoof and hock injuries of dairy cows. J. Dairy Sci. 91:570-576.

Overton, M. W., D. A. Moore, and W. M. Sischo. 2003. Comparison of commonly used indices to evaluate dairy cattle lying behavior. Pages 125-130 in Proc. 5th Intl. Dairy Housing Conf., Fort Worth, TX. American Society of Agricultural Engineers (ASAE), St. Joseph, MI.

Rutherford, K. M. D., F. M. Langford, M. C. Jack, L. Sherwood, A. B. Lawrence, and M. J. Haskell. 2008. Hock injury prevalence ad associated risk factors on organic and nonorganic dairy farms in the United Kingdom. J. Dairy Sci. 91:2265-2274.

Rysanek, D., M. Zouharova, and V. Babak. 2009. Monitoring major mastitis pathogens at the population level on examination of bulk tank milk samples. J. Dairy Res. 76:117-123.

Schnitzer, U. 1971. Abliegen, Liegestellungen und aufstehen beim Rind im Hinblick auf die Entwicklung von Stalleinrichtungen für Milchvieh. Bauschriften des Kuratoriums für Technik und Bauwesen in der Landwirtschaft. Heft 10. Kuratorium für Technik und Bauwesen in der Landwirtschaft, Frankfurt, Germany.

Schulze Westerath, H., L. Gygax, C. Mayer, and B. Wechsler. 2007. Leg lesions and cleanliness of finishing bulls kept in housing systems with different lying area surfaces. Vet. J. 174:77-85.

Tucker, C. B., and D. M. Weary. 2004. Bedding on geotextile mattresses: How much is needed to improve cow comfort? J. Dairy Sci. 87:2889-2895

UGCN (Uiergezondheidscentrum Nederland). 2007. Hygiëne Scorekaart. Dutch Udder Health Centre. Accessed Jan. 2, 2010. http://www.ugcn.nl/media/default.aspx/emma/org/1083484/ F1284539077/ UGCN/hygiene/scorekrt.pdf.

van der Waaij, D., J. M. Berghuis-de Vries, and J. E. C. Lekkerkerkvan der Wees. 1971. Colonization resistance of the digestive tract in conventional and antibiotic-treated mice. J. Hyg. (Lond.) 69:405-411.

van Eerdenburg, F. J. C. M., J. Saltijeral-Oaxaca, and S. VázquezFlores. 2009. Increasing milk yield by improving cow comfort. Pages 143-148 in Proc. European Forum: Livestock housing for the future, Lille, France. Institut de l'Élevage, Paris, France.

Vokey, F. J., C. L. Guard, H. N. Erb, and D. M. Galton. 2001. Effects of alley and stall surfaces on indices of claw and leg health in dairy cattle housed in a free-stall barn. J. Dairy Sci. 84:2686-2699.

Ward, W. R., J. W. Hughes, W. B. Faull, P. J. Cripps, J. P. Sutherland, and J. E. Sutherst. 2002. Observational study of temperature, moisture, $\mathrm{pH}$ and bacteria in straw bedding, and faecal consistency, cleanliness and mastitis in cows in four dairy herds. Vet. Rec. 151:199-206.

Weary, D. M., and I. Taszkun. 2000. Hock lesions and free-stall design. J. Dairy Sci. 83:697-702.

Wechsler, B., J. Schaub, K. Friedli, and R. Hauser. 2000. Behavior and leg injuries in dairy cows kept in cubicle systems with straw bedding or soft lying mats. Appl. Anim. Behav. Sci. 69:189-197. 